دراسة عن بعض حاملى ميكروب البروسيلا في مصر

د. عبد المنعم أحهد سالم - د. عثمان حامد ـ د. عبد الكريم محهود عبد الكريم

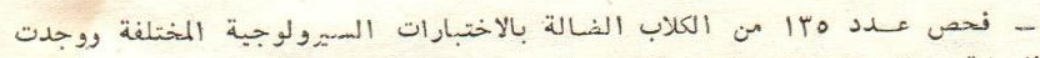

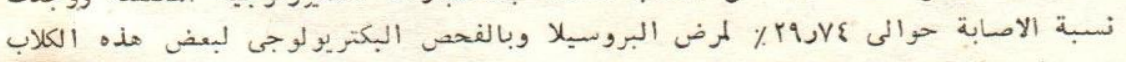

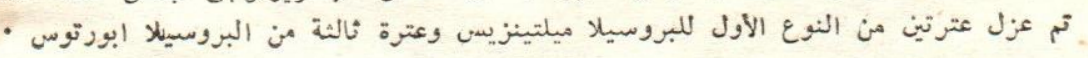

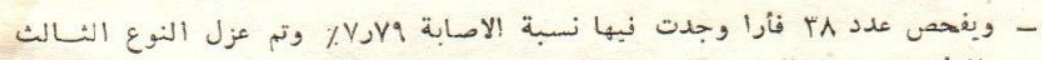

من البروسيلا أبودتوس من الحاى هذه الفئران . 

Department of Veterinary Medicine and Dept. of Hygiene, Faculty

Veterinary Meiicine, Cairo University.

Head of Dept. : Prof. Dr. F. Awad

\title{
STUDIES ON SOME BRUCELLA CARRIERS IN EGYPT
}

\author{
(2 tables)
}

By

\section{A.A. Salem, O.M. Hamed and A·M. Abd-Elkarim}

(Received at $1 / 4 / 1974$ )

\section{SUMMARY}

Serological examination for brucellesis of 135 stray dogs gave $28.88 \%, 28.8 \%$ and $29.6 \%$ of infection by using the slide aggutination tube agglutination and complement fixation tests respectively.

Two strains of $B r$. melitensis biotype 1 an 1 one strain of $\mathrm{Br}$, abortus biotype 3 cou'd be isolated from some serologically reactor degs.

Examination of 38 wild rats by using the slide and tube agglutination tests only, gave $7.79 \%$ of infection. One strain of $\mathrm{Br}$. abortus biotype 3 could be isolat d from some one of these rats,

\section{INTRODUGTION}

HAGAN (1922) was the first to demonstrate brucella infection among the common Brown rat (Rattus norvegicus).

KARKADINOVSKY (1936) examined 34 captured rats from three different infeited premises and recovered Br. abortus from 11 of them. MENTON (1937), FITCH and BISHOP (1938) and MCDIARMID (1951) reported a low incidence of brucellosis among wild rats. BOSWORTH (1937 \& 1940) fcund that five out of 12 rats fed on Br. abortus contaminated materials yield the organism and reported that one out of 167 captured rats from infected dairy farm yielded $\mathrm{Br}$ abortus organisms.

BERECHINKO (1943) reported that dogs are susceptible to Br. melitensis infection, if they are fed on infected faeti, faetal membranes or any other infected materials of sheep or goats. HEISCH, COOKE, HARVEY and DE SOUZA (1963) had isolated Br. suis type III from rodents near Mombasa. 
Mc ERLEAN (1966) reported a case of Br. abortus in a dog suffering from posterior paralysis, arthritis, muscular tremors and undulant fever. CLEGG and RORRISON (1968) reported a case of Br. abortus in a dog suffering from polyarthritis. LEWIS (1972) detected brucella agglutinins during his investigation on 650 dogs.

In the present investigation, dogs and rats have been studied to clear their role in the epidemiology of brucellosis in Egypt.

\section{MATERIALS AND METHODS}

A total of 135 stray dogs and 38 wild rats were collected from different localities in Egypt.

Blood from dogs was procured from the saphina vein or at autopsy for serum collection, while rats were sacrified for the same purpose.

The collected sera were subjected to the following tests :

1. The quantitative plate agglutination test using the Brucella stained antigen (HUDDLESON, 1932).

2. The tube Agglutination test was used according to the technique of the Central Veterinary Laboratory, Weibridge England (ALTON and JONES, 1967).

3. The complement Fixation test according to TRILENKO

This test was applied only to dog's sera which were inactivated by incubation in water bath at $60^{\circ} \mathrm{C}$ for 30 minutes. Two serum dilutions $1: 5$ and 1 : 10 were used.

The spleen, liver, kidneys, lymph nodes and the urinary bladders of serologically reactors 11 dogs and 3 rats were subjected to bacteriological examination for isolation of brucella organisms. Isolation was conducted by culture method and animal inoculation. Meat-liver infusion agar media were used for isolation. Inoculated media were incubated at $37^{\circ} \mathrm{G}$ under $5-10 \%$ $\mathrm{CO}_{2}$ tension, as well as under normal atmospheric condition.

For animal inoculation two brucella free guinea pigs were used for each sample. The inoculation of the laboratory animals were conducted subcutaneously or intramuscularly. The animals were killed 4-6 weeks after inoculation. Blood was collected from the heart just before killing for serological examination. At autopsy, lesions were noted and cultures were made from the lymph nodes, bone marrow and internal organs.

Assiut Vet. Med. J., Vol. 1, No. 1 and 2, 1974. 
Suspected colonies were confirmed as brucella by microscopical examinaation of stained smears as well as by the agglutination with a known positive brucella serum and not with a negative one.

Typing of the Brucella isolates was carried out according to the methods recommended by the International Committee of Taxonomy of FAO/WHO for typing of Brucella Organisms (Report of International Committee of Nomenclature of bacteria, 1967). Before typing of the isolates, they were proved to be in smooth form by using the methods recommended by BRAUN and BONESTELL (1947), WHITE and WILSON (1951) and by the thermoprecipitation test.

\section{RESULTS}

The results of the serodiagnostic tests are shown in Table I.

TABLE 1: Showing the results of serodiagnostic tests on dogs and rats

\begin{tabular}{|c|c|c|c|c|c|c|c|}
\hline \multirow{2}{*}{ Species } & \multirow{2}{*}{$\begin{array}{c}\text { Total } \\
\text { No. } \\
\text { tested }\end{array}$} & \multicolumn{2}{|c|}{ SAT } & \multicolumn{2}{|c|}{ TAT } & \multicolumn{2}{|c|}{ CFT } \\
\hline & & Positive & $\%$ & Positive & $\%$ & Positive & $\%$ \\
\hline $\begin{array}{l}\text { Dogs } \\
\text { Rats }\end{array}$ & $\begin{array}{r}135 \\
38\end{array}$ & $\begin{array}{r}39 \\
3\end{array}$ & $\begin{array}{r}28.8 \\
7.8\end{array}$ & $\begin{array}{r}26 \\
5\end{array}$ & $\begin{array}{r}19.2 \\
7.8\end{array}$ & $\begin{array}{l}40 \\
\text { not }\end{array}$ & $\begin{array}{l}29.6 \\
\text { ne }\end{array}$ \\
\hline
\end{tabular}

$\mathrm{SAT}=$ Slide agglutination test.

TAT $=$ Tube agglutination test.

$\mathrm{CFT}=$ Complement fixatic $\mathrm{n}$ test.

The results of bacteriological examination of 11 serologically positive dogs and 3 rats are given in Table II.

TABLE 2: Showing the types of Brucella organisms isolated from seropositive dogs and rats

\begin{tabular}{|c|c|c|c|c|c|c|}
\hline \multirow{2}{*}{ Species } & \multicolumn{3}{|c|}{ Serodiagnostic test } & \multicolumn{2}{|c|}{ Isolation } & \multirow[b]{2}{*}{ Typing } \\
\hline & TAT & $\begin{array}{l}\text { Titre of } \\
\text { SAT }\end{array}$ & CFT & Culture & G. pig & \\
\hline $\begin{array}{l}\text { Dogs... } \\
\text { Rat . . . }\end{array}$ & $\begin{array}{l}+ \\
+ \\
+ \\
+\end{array}$ & $\begin{array}{l:l}1 & : 80 \\
1 & : 160 \\
1 & : 160 \\
1 & : 40\end{array}$ & $\begin{array}{c}+ \\
+ \\
+ \\
\text { Note done }\end{array}$ & $\begin{array}{l}- \\
+ \\
+ \\
+\end{array}$ & $\begin{array}{l}+ \\
+ \\
+ \\
+\end{array}$ & $\begin{array}{lll}\text { Br. abortus biotype } & 3 \\
\text { Br. melitensis ," } & 1 \\
\text { Br. melitensis ," } & 1 \\
\text { Br. abortus ," } & 3\end{array}$ \\
\hline
\end{tabular}

$\mathrm{SAT}=$ Slide agglutination test

$\mathrm{TAT}=$ Tube agglutination test.

CFT $=$ Complement fixation test.

Assiut Vet. Med. J., Vol. 1, No. 1 and 2, 1974. 


\section{DISCUSSION}

Brucellosis has been implicated in causing great economical losses to animal industry, MEYER (1956), ORLOV (1958) and others. Control of brucellosis is a difficult task, specially in areas where straying of animals as dogs are actively taking place.

The present study was carried out to investigate the possibility of reserv- oirs remaining among some straying animals in Egypt ; that co-habit with our grazing or housed stock and even with man ; in order to clearify their role in the epidemiology of brucellosis.

Serological investigation of 135 stray dogs by using the slide agglutination, tube agglutination and complement fixation tests gave $21.4 \%, 19.2 \%$ and $28.8 \%$ infection respectively. Bacteriological examination of 11 serologically positive dogs gave two strains of $\mathrm{Br}$ melitensis biotype 1 and one strain of $\mathrm{Br}$. abortus biotype 3. These findings are supported by BERECHINKO (1943), McERLEAN (1966) and CLEGG and RORRISON (1968). The high incidence of brucellosis among dogs and their susceptibility to the infection, not only with $\mathrm{Br}$. abortus, but also with $\mathrm{Br}$. melitensis in Egypt, should be taken in consideration, because these dogs can propagate this disease among animals and man.

Three out of 38 examined rats were positively reactors to the slide agglutination and the agglutination tests.

Bacteriological examination of these three rats yielded one strain of $\mathrm{Br}$. abortus biotype 3. These results are supported by HAGAN (1922), BOSWORTH (1937 \& 1940), KARKADINOVSKY (1936), MENTON (1937), FITCH and BISHOP (1938) and MCDIARMID (1951).

The results of the present investigation proved the existance of brucella infection in stray dogs and rats in Egypt. These animals act as scavengers and are capable of transmitting brucella infection to domestic animals and man by contaminating pastures, food or water troughs with their discharges.

Therefore dogs and rats in Egypt can act as potential source for dissimination of brucella infection and this should be taken in consideration in organizing control programes for eradcation of brucellosis. 


\section{REFERENCES}

Alton, G.G. and Jones, L.M. (1967) : Laboratory techniques in brucellosis. Wld. Hlth. Org. Tech. Report Ser., $55: 9-54$.

Bosworth, T.J. (1937) : The susceptibility of the wild rat to infection with Brucella abortus. A preliminary note. J. Comp. Path., $50: 345-349$.

Bosworth, T.J. (1940) : Further observation on the wild rat as a carrier of Brucella abortus. J. Comp. Path., $53: 42$ - 49.

Berechinko, N.V. (1943) : Susceptibility of dogs to brucellosis. Trode Trotckova Veterinarnova, 1st and Voennova Vet. Lab. Or. Bo., $4: 50$.

Braun, W. and Bonestell, A.E. (1947) : Independent variants of characteristics of $\mathrm{Br}$. abortus variants and their detection. Amer. J. Vet. Res., $8: 386$.

Clegg, F.G. and Rorrison, J.M. (1968) : Br. abortus infection in dog, a case of polyarthritis. Res. Vet. Sci., $9: 183-185$.

Fitch, C.P. and Bishop, L.M. (1938) : The wild rat as a host to Brucella abortus. Cornell Vet., $28: 304-306$.

Hagan, W.A. (1922) : The susceptibility of Mice \& Rats to infection with Brucella abortus. J. Exp. Med. $36: 727-731$.

Heiseh, R.B., Cooke, E.R.N., Harvey A.E. and De Souza, F. (1963) : The isolation of Brucella suis from rodents in Kenya. East African M. J., 40 : $132-133$.

Huddleson, I.F. (1932) : cited in Hagan, W. \& Bruner, D.W. (1961) : The Infectious Diseases of Domestic Animals. 4th ed. Ithaca, New York, p. 276.

Karkadinovsky, S.A. (1936) : Sur la Brucellose des Rats gris sauvage. C.R., Séanc. Soc. Biol., $121: 1611-1613$.

Lewis, G.E. (1972) : Serological survey of 650 dogs to detect titre of Brucella canis (Br suis type 5). J. Amer. Animal Hospital Assoc., 8 (2) : 102 - 107.

McDiarmid, A. (1951) : The occurrence of agglutinins for Br. abortus in the blood of wild deer in the South of England. Vet. Rec., $63: 469-470$.

McErlean, B.A.(1966) : Undulating fever, posterior paresis and arthritis in a dog apparantly due brucellosis. Vet. Rec., $79: 567-569$.

Menton, J. (1937) : Brucellosis in Man Animals in Staffordshire : Laboratory Observation. Br. Med. J. Dce., $25: 1273-1275$.

Meyer, K.F. (1956) : Trends in Brucellosis control. Public Hlth. Rep., Wash., 71 : 511.

Orlov, E.S. (1958) : Studies of Brucellosis in sheep. Thesis D.Sc., Moscow, USSR.

Report of International Committee on Nomenclature of bacteria by the subcommittı on Taxonomy of Brucella minutes. International Journal of Systemic Bacteriology, 1967, $17: 371-375$.

Trilenko, P.A. (1956) : Diagnosis of infections abortion. 2nd ed., 75-117. Silkhozgiz, Moscow, USSR.

White, P.G. and Wilson, J.B. (1951) : Differentiation of smooth and non-smooth colonies of Brucella. J. Bact., $61: 239-241$.

Author's address: A.A. SALEM. Dept of Med. Fac. of Vet. Med. Cairo Univeraty.

Assiut Vet. Med. J., Vol. 1, No. 1 and 2, 1974. 


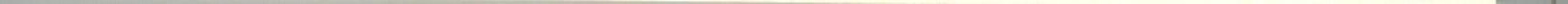

